DOI: 10.17707/AgricultForest.61.3.10

\begin{abstract}
Mahdi FARAVANI, M H KHAN, Barat Ali GHOLAMI, Gholam Ali QAZANCHIAN, Davood Ali SAGHI,
\end{abstract}

\title{
VARIABILITY STUDIES OF SOME BLACK CARAWAY (Bunium persicum BIOSS. FEDTS) ACCESSIONS ACROSS IMPORTANT GROWING SITES OF IRAN
}

\begin{abstract}
SUMMARY
The present study was conducted at KANRRC to analyse the variability parameters of some Bunium persicum accessions during 2010-2015. The analysis of variance exhibited significant variation among the accessions for all the traits under study. Phenotypic coefficient of variation (PCV) was higher than the genotypic coefficient of variation $(\mathrm{GCV})$ for all the traits indicating that all these characters had interacted with the environment. Moderate coefficient of variation (genotypic and phenotypic) was observed for number of seeds umbelt ${ }^{-1}$ and plant biomass plant ${ }^{-1}$ indicating fair amount of variability present for the traits under mention. High heritability estimates were recorded for all the traits except plant height where the heritability was moderate. High heritability accompanied by high genetic advance was observed for number of seed umblet ${ }^{-1}$, umblet plant ${ }^{-1}$, total plant weight, number of umbel $^{-1}$ and bio yield. The genotype Khajeh forest was significantly superior with regard to number of seed umblet $^{-1}$, seed yield, bio yield and yield of essential oil. The accessions viz., Brown Ferdows, Khajeh forest, Chelmir and Chenaran-Frizi were found potential donors for seed yield and yield of essential oils.
\end{abstract}

Keywords: Characterization, black caraway, morphological traits, yield and yield attributes

\section{INTRODUCTION}

Black caraway (Bunium persicum Boiss.) is a perennial aromatic and medicinal herb, distributed in temperate areas of the world and mostly restricted to the sub- alpine mountain slopes (Dar et al., 2011). Its species grow wild in North Himalayan regions, Iran, Pakistan and generally it is native to central and Southern parts of Asia, with a wide geographical distribution in Iran. At present, seeds of this valuable medicinal spice plant are extensively collected from natural habitats (Khosravi, 2005), in forests and grasslands in India, at higher elevations including arid zones ranging from $1600 \mathrm{~m}$ to $3300 \mathrm{~m}$ above sea level. In Iran, it is distributed at higher elevations, such as mountains which are colder than

\footnotetext{
${ }^{1}$ Mahdi Faravani, (corresponding author: mfaravani@gmail.com), Barat Ali Gholami, Gholam Ali Qazanchian, Davood Ali Saghi, Division of Natural Resources, KANRRC. AREO, Mashhad, Khorassan Razavi, 91735-488, IRAN.

M H Khan, Department of Agriculture, Srinagar (J\&K) INDIA - 190001

Notes: The authors declare that they have no conflicts of interest. Authorship Form signed online.
} 
surrounding lowlands mainly in the North-East as in Semnan Qazvin, Hormozgan, Esfahan, Razavi Khorasan, Yazd, Fars, Arak and Kerman. The crop mostly grow as wild under natural conditions in mountain, open hilly grassy slopes, low alpine and table lands, as sub - populations, mostly across the hilly areas. The sub-populations across the state represent a great diversity of this plant species which is naturally maintained as valuable germplasm repositories and are the sources of high genetic variability.

One of the primary objectives of breeders is to increase the seed yield. Generally, yield represents the final character resulting from many developmental and biochemical processes (Mishra and Tewari, 2014), which occur between germination and maturity. Before yield improvements can be realized, the breeder needs to identify the causes of variability in yield in any given environment. Since fluctuation in environment generally affects yield primarily through its components. Grafius (1960) suggested that individual yield components may contribute valuable information in breeding for yield. Yield when viewed from the mechanistic or geometric point of view is a product of its components. Knowledge of genetic variability in a given crop is essential for successful breeding improvement programme. To develop of high yielding cultivars it requires a thorough knowledge of the existing variability and association for yield contributing traits in the available germplasm. This will enable him to know how the selection pressure exerted by him on one trait will cause changes in other traits (Al-Aysh et al., 2014). The present study was conducted with an objective to estimate genetic variability with the aid of genetic parameters such as genotype coefficient of variation (GCV), phenotypic coefficient of variation (PCV), heritability (h) and genetic advance.

The present investigation was taken up to elicit information for various morphological, yields and yield attributing traits of Black caraway. The study was carried out during 2010 and 2015. The seeds and bulbs of plant populations of Black Caraway were collected from the wild areas of provinces of Semnan (the mountain ZAR Damghan), Qazvin (Alamut mountain), Hormozgan (Geno mountain Bandar Abbas), North and South (Santa Aman mosque, Esfahan, Razavi Khorasan (a mountain of Akhlamad, Kashmar, Bajestan, Kalat, Chenaran, and altitude of Mashhad), Yazd (Lakheh Mehriz mountain), Fars (Toodj Estahban Mountain), Markazi (Black Mountain) and the Kerman (Barez mountain). The seeds were planted in the separate plots. Experimental was laid in a randomized block design with three replications. Each line was grown in two rows of $3 \mathrm{~m}$ length, spaced at $50 \mathrm{~cm}$, keeping plant to plant distance of $10 \mathrm{~cm}$. The recommended packages of practices were followed to raise a healthy crop. During the third year of experiment, 5 plants were randomly selected from each accession in each plot and tagged for recording the observations on the following traits viz., plant height, plant seed weight, number of seed umblet ${ }^{-1}$, umblet plant ${ }^{1}$, total plant weight, number of umbel ${ }^{-1}$, umblet umbel ${ }^{-1}$, number of main branch, 1000 -seed weight $(\mathrm{g})$, seed yield $\left(\mathrm{g} \mathrm{m}^{-2}\right)$, bio yield $\left(\mathrm{g} \mathrm{m}^{-2}\right)$, essential oil $(\%)$, yield of essential oil $\left(\mathrm{g} \mathrm{m}^{-2}\right)$ and harvest index 
Standard statistical procedure were used for the analysis of variance, genotypic and phenotypic coefficients of variation (Burton, 1952), heritability (Hanson et al., 1956) and genetic advance (Johnson et al., 1955). The computer software system of SAS (Institute, 2002) was used for analysis of data.

\section{RESULTS AND DISCUSSION}

The analysis of variance (Table 1) showed significant differences for all the characters studied except number of umbels and thereby provides an opportunity for selecting suitable genotypes with better performance for the traits. This further indicated that the genotypes selected in the present study were exhibiting considerable variation for almost all the traits. Similar results were also reported by Dar et al. (2011) and Devi (2004) who also reported high amount of variability between the collections. Improvement through breeding programme in any crop is dependent on the availability of information on genetic variability. The observed variability in crop plants is normally due to the variation in qualitative and quantitative heritability fractions influenced considerably by prevailing environmental condition. It is, therefore, desirable to study the nature of exhibited variability and to exploit same in the crop improvement programmes.

Variability in the population, especially in respect to the characters for which improvement is sought, is a prerequisite for successful selection. The estimates of phenotypic coefficient of variation (PCV) in general, were higher than the estimates of genotypic coefficient of variation (GCV) for all the characters (Table 2), indicating that all the characters had interacted with the environment. This suggested that apparent variation in all these characters is not only due to genotype but also due to the influence of environment and selection for such traits may not be reliable. These results are in close agreement with the earlier reports of Dar et al., (2011) and Azimzadeh et al., (2012). The estimates of genotypic coefficient of variation ranged from 0.07 - 1.98. The value was highest for yield of essential oil $\left(\mathrm{g} \mathrm{m}^{-2}\right)(1.98)$ which was closely followed by harvest index (1.88), bio yield $\left(\mathrm{g} \mathrm{m}^{-2}\right)(1.80)$ and seed yield $\left(\mathrm{g} \mathrm{m}^{-2}\right)(1.54)$. This is indicative of less amenability of these traits to environmental fluctuations and hence, greater emphasis should be given to these characters, while breeding cultivars from the present material. The lowest genotypic coefficient of variance was recorded in number of main branch $(0.07)$ followed by plant height $(0.11)$, 1000 -seed weight $(\mathrm{g})(0.32)$, umblet umbel $^{-1}(0.51)$ and essential oil (\%) (0.57). the low GCV suggests that the breeders should go for source of high variability for improvement in these traits. For rest of the characters the genotypic coefficient of variation (GCV) was found moderate. 
Table 1. Analysis of variance for 14 characters in Black Caraway

\begin{tabular}{|c|c|c|c|c|}
\hline 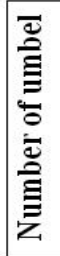 & 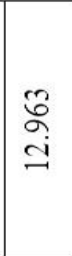 & 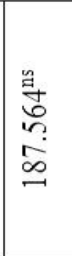 & 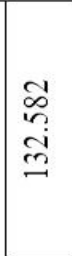 & 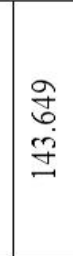 \\
\hline 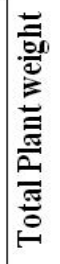 & 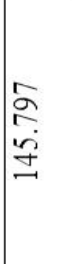 & 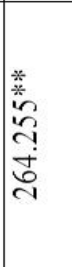 & 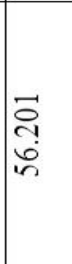 & 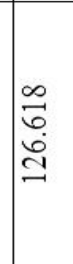 \\
\hline 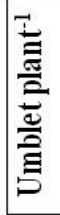 & 童 & $\begin{array}{l}\tilde{a} \\
\tilde{\sigma} \\
\tilde{2} \\
\infty \\
\sim \\
\sim\end{array}$ & $\begin{array}{l}\overline{6} \\
\frac{8}{\infty} \\
m\end{array}$ & $\begin{array}{l}\hat{\sigma} \\
\text { రి } \\
\text { సి }\end{array}$ \\
\hline 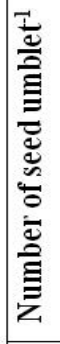 & 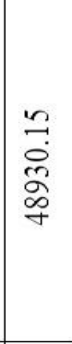 & 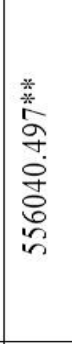 & 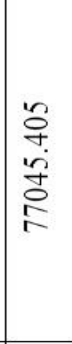 & 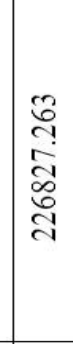 \\
\hline 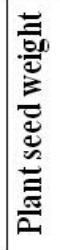 & $\underset{\stackrel{y}{y}}{\stackrel{\sim}{c}}$ & 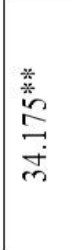 & 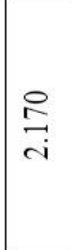 & 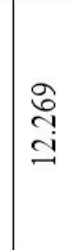 \\
\hline 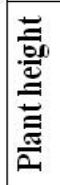 & $\begin{array}{l}\tilde{n} \\
\tilde{6} \\
\dot{n}\end{array}$ & \begin{tabular}{l} 
\%े \\
के \\
\multirow{0}{0}{} \\
ర్
\end{tabular} & $\begin{array}{l}\vec{\infty} \\
\infty \\
\infty\end{array}$ & 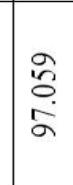 \\
\hline$E$ & $\sim$ & ב & さ & $\infty$ \\
\hline 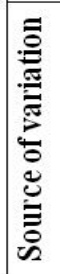 & 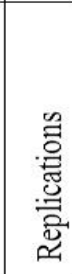 & 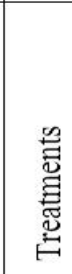 & 营 & 丞 \\
\hline
\end{tabular}

\begin{tabular}{|c|c|c|c|c|}
\hline 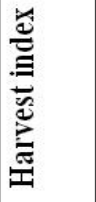 & $\begin{array}{l}\circ \\
\circ \\
\circ\end{array}$ & 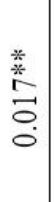 & $\begin{array}{l}\text { ㅇ' } \\
\text { ¿े }\end{array}$ & $\begin{array}{l}\hat{8} \\
\stackrel{0}{0}\end{array}$ \\
\hline 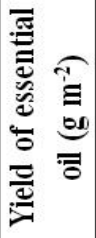 & $\begin{array}{l}m \\
\ddot{b} \\
0\end{array}$ & $\begin{array}{l}* \\
\vec{\sigma} \\
\stackrel{0}{0} \\
\end{array}$ & 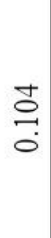 & $\begin{array}{l}\vec{\infty} \\
\overrightarrow{0}\end{array}$ \\
\hline 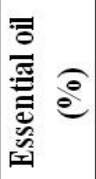 & 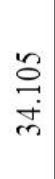 & $\stackrel{*}{\ddot{*}}$ & $\begin{array}{l}\vec{\circ} \\
\stackrel{n}{-}\end{array}$ & $\begin{array}{l}n \\
\vec{a} \\
m\end{array}$ \\
\hline 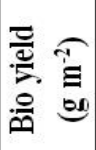 & 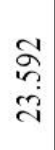 & $\begin{array}{l}\stackrel{*}{*} \\
\stackrel{+}{ \pm} \\
m \\
m \\
\ddot{z}\end{array}$ & $\begin{array}{l}\stackrel{\Xi}{\Xi} \\
\underset{\Xi}{ \pm}\end{array}$ & $\begin{array}{l}\infty \\
b \\
\sim \\
i \\
n\end{array}$ \\
\hline 胥 & $\begin{array}{l}\stackrel{2}{q} \\
\stackrel{\sim}{\sim}\end{array}$ & $\begin{array}{l}\stackrel{*}{*} \\
\stackrel{7}{7} \\
\dot{8} \\
\dot{0}\end{array}$ & $\begin{array}{l}c \\
01 \\
\infty \\
0 \\
0 \\
0\end{array}$ & 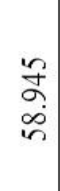 \\
\hline 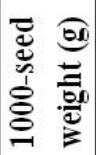 & $\begin{array}{l}n \\
\infty \\
\vdots \\
0\end{array}$ & 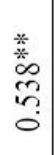 & $\begin{array}{l}2 \\
8 \\
0 \\
0\end{array}$ & $\begin{array}{l}\vec{\sigma} \\
\overrightarrow{0}\end{array}$ \\
\hline 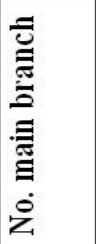 & 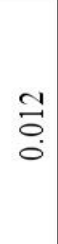 & 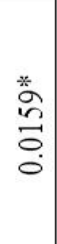 & $\begin{array}{l}\circ \\
8 \\
\circ \\
\circ\end{array}$ & $\begin{array}{l}0 \\
\circ \\
8 \\
\circ\end{array}$ \\
\hline 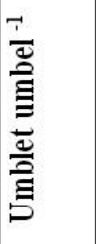 & $\begin{array}{l}2 \\
\stackrel{\circ}{\circ} \\
\stackrel{0}{0}\end{array}$ & $\begin{array}{l}a \\
\tilde{a} \\
2 \\
\alpha \\
\infty \\
\sim\end{array}$ & $\begin{array}{l}\hat{\sigma} \\
\stackrel{\pi}{-} \\
\dot{\pi}\end{array}$ & 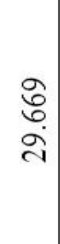 \\
\hline
\end{tabular}


Dar et al. (2011) also noticed the moderate genotypic coefficient of variation for such traits and suggested that these traits can be improved by the vigorous selection. The estimates of phenotypic coefficient of variation (PCV) also followed the similar trend. The magnitude of PCV ranged from 0.08 for number of main branch to 2.09 for yield of essential oil. The characters with high phenotypic coefficient of variation indicated more influence of environmental factors. Therefore, caution has to be exercised during the selection program because the environmental variations are unpredictable in nature and may mislead the results. In the earlier studies also, Devi (2004), Majeed and Sharma (2006), Dar et al., (2011) and Azimzadeh et al., (2012) observed high genotypic and phenotypic coefficient of variation for the above studied traits.

The coefficient of variability does not give any idea regarding the heritable portion of the variability; it can be ascertained by working out the heritability estimates. Heritability in narrow sense is the ratio of additive genotypic variance to the total variance and in broad sense it is the ratio of genotypic variance to the phenotypic variance (Lush, 1949). In the present study heritability in broad sense is estimated. Encouraging results were obtained with respect to the heritability of the characters studied except for plant height. It could be observed from Table 2 that heritability estimates ranged from 0.61 to 0.98 . The heritability estimates was highest for plant seed weight, seed yield $\left(\mathrm{g} \mathrm{m}^{-2}\right)$, bio yield $\left(\mathrm{g} \mathrm{m}^{-2}\right)(0.98 \mathrm{each})$ which was closely followed by number of seed umblet ${ }^{-1}(0.96)$, harvest index (0.95), total plant weight (0.94) and number of main branch and 1000-seed weight $(\mathrm{g})(0.91 \mathrm{each})$ which suggested that the characters are least influenced by the environmental factors and also indicates the dependency of phenotypic expression which reflects the genotypic ability of cultivars to transmit the genes to their off-springs. High heritability estimates for various characters have also been reported by Puschmann et al. (1992), Pank and Quilitzsch (1996) in caraway (Carum carvi), Kapila et al. (1997), Dar et al., (2011) and Azimzadeh et al., (2012) in Black Caraway (Bunium persicum). The lowest value of heritability was recorded for plant height $(0.61)$ which indicates the character is highly influenced by environmental effects and genetic improvement through selection will be difficult. For rest of the characters, the estimates of heritability were found moderate. Characters with moderate heritability indicated that they are not dependable as their genotypic expression is superimposed by the environmental influences (Allard, 1960). Thus the degree of success through selection depends also upon magnitude of heritability values. Furthermore selection is also directly proportional to the amount of genetic advance.

Through the heritability estimates indicate the efficiency of selection system. Yet their scope is restricted as they are prone to change with environment, material used, etc. hence, more reliable information can be had from heritability estimates coupled with genetic advance rather than heritability alone in framing the selection procedure (Johnson et al., 1955). The genetic advance expressed as percentage of mean ranged from as low as 2.30 for number of main branches to as high as 4990.91 for number of seed umblet ${ }^{-1}$. 
Table 2. Estimate of mean, components of variance, heritability (bs) and expected genetic advance in respect of 14 characters in black caraway

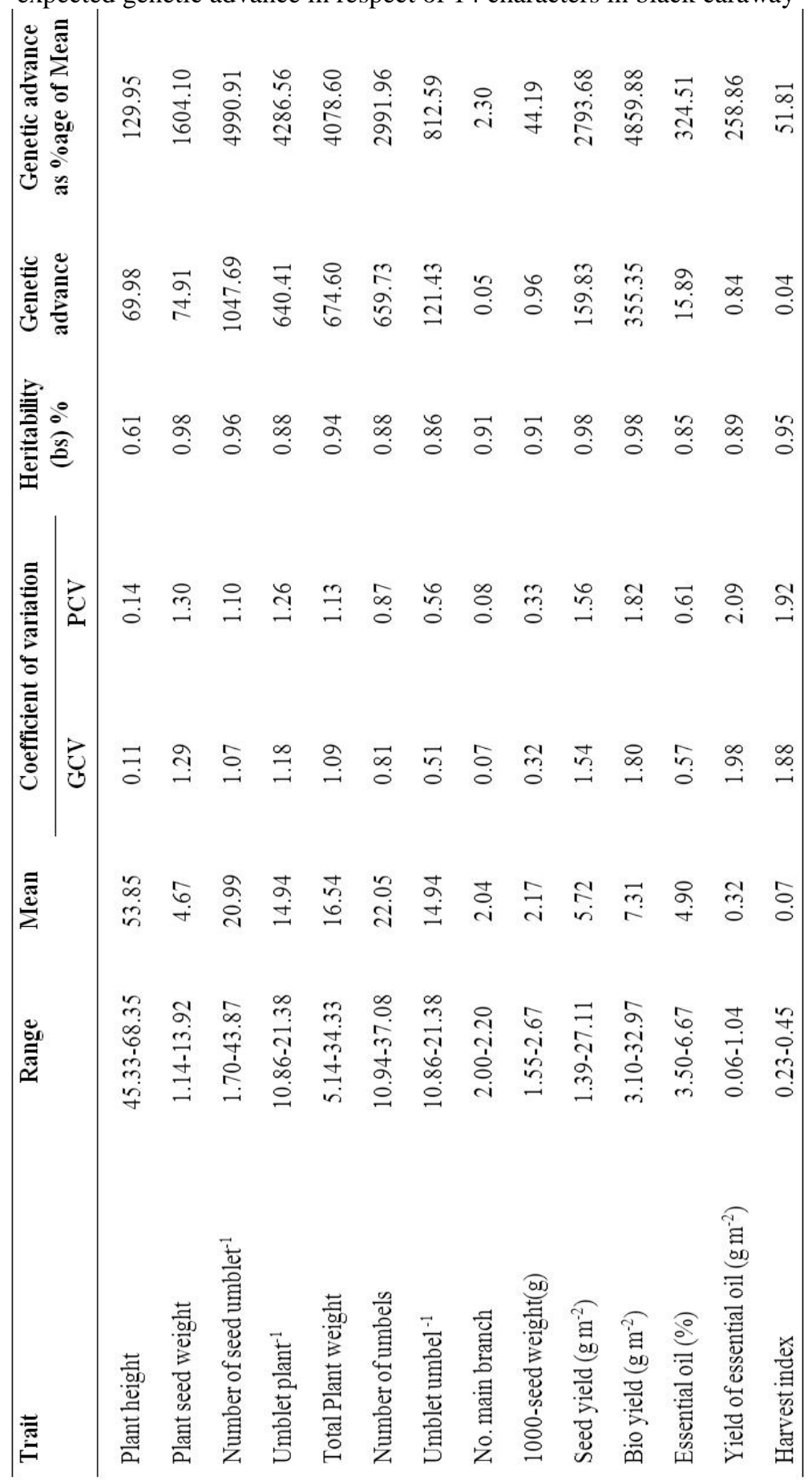


Table 3. Comparison of different traits measured in 13 selected genotypes

Bunium persicum L. using Duncan's multiple range tests at 5\% level.

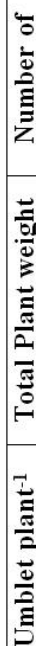

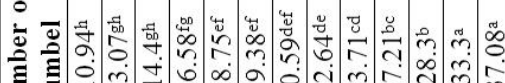

E

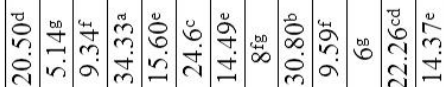

焉

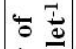

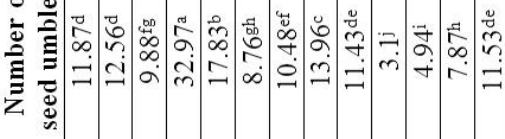

ช్

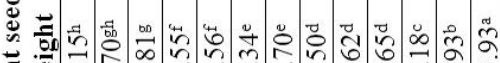
言
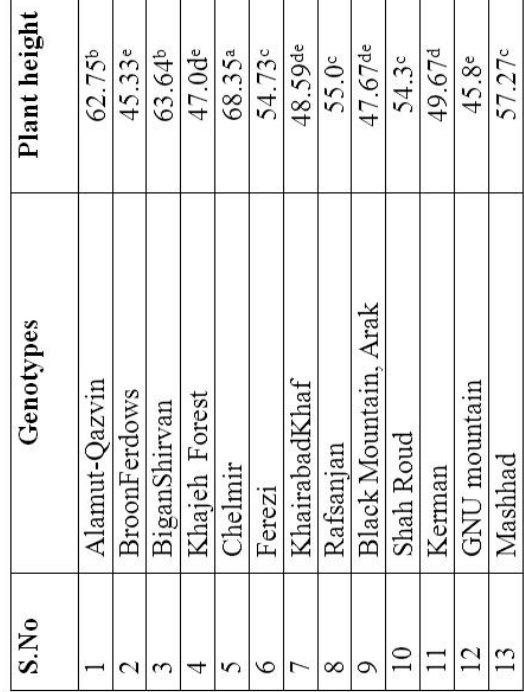
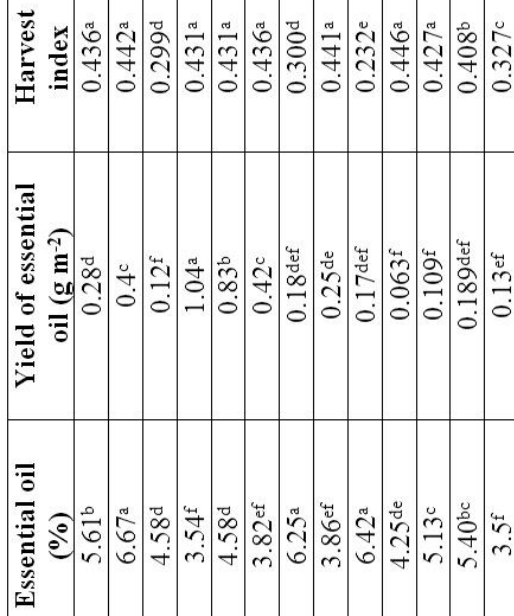

중

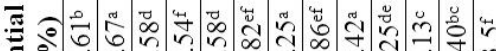
क 되

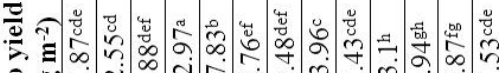
.

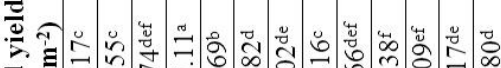

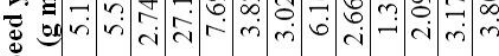

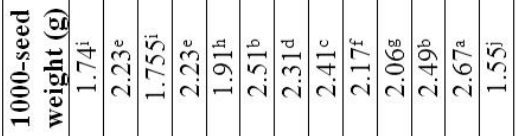

シ $\dot{0}$

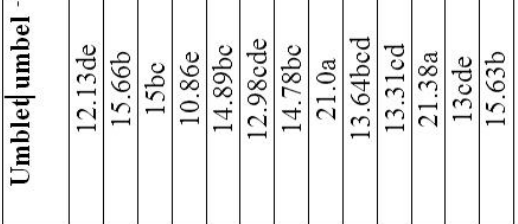


In general, the expected genetic advance as per cent of mean for majority of traits was high, which indicates that traits are governed by additive genes and selection will be rewarding for improvement of each trait. High heritability coupled with high genetic advance was observed for number of seed umblet ${ }^{-1}$, umblet plant ${ }^{-1}$, and total plant weight, number of umbel ${ }^{-1}$ and bio yield $\left(\mathrm{g} \mathrm{m}^{-2}\right)$ and thereby showing additive gene effect. Characters showing high heritability with high genetic advance may be due to additive gene action (Panse, 1957) and thus, could be improved upon by adapting selection without progeny testing. High heritability accompanied with low genetic advance were recorded for essential oil (\%), yield of essential oil $\left(\mathrm{g} \mathrm{m}^{-2}\right)$ and harvest index which indicates the presence of non-additive type of gene action. Panse (1957) reported that high heritability correlated with low genetic advance indicates non- additive gene effects. The high heritability is being exhibited due to favourable influence of environment rather than genotype and selection for such traits may not be rewarding. For rest of the characters the heritability accompanied with genetic advance were found moderate. The above results are in similarity with the findings of Majeed and Sharma (2006), Dar et al., (2011) and Azimzadeh et al., (2012).

The comparison of various morphological traits using Duncan's multiple range tests revealed significant variation among the 13 ecotypes of Bunium persicum (Table 3). The genotype Chelmir was the tallest plant $(68.35 \mathrm{~cm})$ and was significantly superior to other genotypes, while the genotypes Geno mountain was significantly inferior with regard to the plant height. Mashhad recorded significantly highest plant seed weight, while the lowest seed weight was recorded in Alamut Qazvin. The genotype Khajeh forest was significantly superior with regard to number of seed umblet ${ }^{-1}$ (32.97), seed yield $\left(27.11 \mathrm{~g} \mathrm{~m}^{-2}\right)$, bio yield $\left(32.97 \mathrm{~g} \mathrm{~m}^{-2}\right)$ and yield of essential oil $\left(1.04 \mathrm{~g} \mathrm{~m}^{-2}\right)$, however, the same genotype recorded significantly lowest percentage of essential oil. Brown Ferdows being at par with Arak and Khairabad Khaf recorded significantly higher percentage of essential oil. Similarly, Ferezi and Shah Roud recorded significantly highest number of main branches per plant among the 13 genotypes. The genotypes Geno Mountain and Mashhad exhibited significantly highest and lowest 1000-seed weight, respectively. Based on the Duncan's multiple range test potential donors for growth, yield and yield attributes of Bunium persicum were calculated (Table 4). The data revealed that the genotypes viz., Brown Ferdows, Khajeh forest, Chelmir and Chenaran-Ferezi were found potential donors for seed yield and yield of essential oil, Brown Ferdows, Khari Abad Khaf and Arak for essential oil per cent, Brown Ferdows, Rafsanjan and Kerman for number of umbels and umblet umbel ${ }^{-1}$. In general the genotypes Khajeh forest and Chelmir were found potential donors for almost all the traits. 
Table 4. Potential donor accessions for yield and other recorded traits

\begin{tabular}{|c|c|c|}
\hline S. No. & Characters & Accessions Potential Donors \\
\hline 1 & Plant height & $5,3,1$ \\
\hline 2 & Plant seed weight & $4,5,3,1$ \\
\hline 3 & Number of seed umblet ${ }^{-1}$ & $4,5,8,2$ \\
\hline 4 & Umblet plant $^{-1}$ & $3,1,4$ \\
\hline 5 & Total Plant weight & $4,5,8$ \\
\hline 6 & Number of umbels & $11,8,2,13$ \\
\hline 7 & Umblet umbel $^{-1}$ & $11,8,2,13$ \\
\hline 8 & No.Main branch & $6,10,9$ \\
\hline 9 & 1000 -seed weight $(\mathrm{g})$ & $12,6,11,8$ \\
\hline 10 & Seed yield $\left(\mathrm{g} \mathrm{m}^{-2}\right)$ & $4,5,8,2,1$ \\
\hline 11 & Bio yield $\left(\mathrm{g} \mathrm{m}^{-2}\right)$ & $4,5,8$ \\
\hline 12 & Essential oil (\%) & $2,9,7$ \\
\hline 13 & Yield of essential oil $\left(\mathrm{g} \mathrm{m}^{-2}\right)$ & $4,5,6,2$ \\
\hline 14 & Harvest index & $10,2,8,6,1,5,4,11$ \\
\hline
\end{tabular}

where, 1, 2, 3, 4, 5, 6, 7, 8, 9, 10, 11, 12 and 13 are Alamut-Qazvin, Brown Ferdows, Biganshirvan, Khajeh forest, Chelmir, Chenaran-Ferezi, Khaf, Rafsanjan, Arak, Shahrud, Kerman, Geno mountain and Mashhad, respectively.

\section{CONCLUSIONS}

High heritability accompanied by high genetic advance was observed for number of seed umblet ${ }^{-1}$, umblet plant ${ }^{-1}$, total plant weight, number of umbel ${ }^{-1}$ and bio yield. Therefore, it is concluded that these traits had to be accounted for direct selection for the improvement of yield. From this point, the genotype Khajeh forest was significantly superior with regard to number of seed umblet ${ }^{-1}$, seed yield, bio yield and as well for the yield of essential oil.

\section{ACKNOWLEDGEMENTS}

This study was supported by the Khorasan Razavi Agricultural and Natural Research and Education Centre. Special thanks are due to Abdoul Karim Negari, Department of Natural Resources Research, for assistance in field work and laboratory research.

\section{REFERENCES}

Allard, I., 1960. Principles of Plant Breeding, Chapter 6 through Chapter 9, University of California, Davis. California, John Wiley \& Sons, New York.

Al-Aysh, F., Al-Abdalla, N., Al-Nabelssi, A., 2014. Phenotypic adaptability and stability of macrosperma lentil landraces in Dara'a Govrenorate, Syria. Agriculture \& Forestry (Podgorica) 60, 169-179. 
Azimzadeh, J., Wong, M.L., Downhour, D.M., Alvarado, A.S., Marshall, W.F., 2012. Centrosome loss in the evolution of planarians. Science 335, 461-463.

Burton, G.W., 1952. Quantitative inheritance in grasses. Proc. 6th Int. Grassland Cong 1, 277-283.

Dar, Z.A., Zeerak, N., Wani, S.A., Khan, M., 2011. Morpho-characterization of different populations of black caraway (Bunium persicum Bioss. Fedts) with respect to yield and yield traits across important growing sites of Kashmir Valley. Journal of Agricultural Biotechnology and Sustainable Development 3, 60-64.

Devi, S., 2004. Evaluation of Bunium persicum (Boiss.) B. Fedtsch. germplasm in Himachal Peradesh. Ph. D. Thesis.

Grafius, J., 1960. Does overdominance exist for yield in corn? Agronomy Journal 52.

Hanson, C., Robinson, H., Comstock, R., 1956. Biometrical studies of yield in segregating populations of Korean Lespedeza. Agronomy Journal 48, 268-272.

Institute., S., 2002. JMP user's guide. SAS Institute Cary, NC.

Johnson, H.W., Robinson, H., Comstock, R., 1955. Estimates of genetic and environmental variability in soybeans. Agronomy journal 47, 314-318.

Kapila, R., Panwar, K., Badiyala, D., 1997. Variation and association analysis in domesticated population of Black caraway (Bunium persicum). J Med Arom Plant Sci 19, 709-711.

Khosravi, M., 2005. Intercropping Black Zira (Bunium persicum) with Saffron and annual crops: Agroecological and economic perspectives. Ph. D. Thesis.

Lush, J.L., 1949. Heritability of quantitative characters in farm animals. Hereditas 35, 356-375.

Mishra, A. and Tewari, N. 2014. Effect of Date of Sowing on Yield and Yield Components of Castor (Ricinus communis L.) Cultivars under Irrigated Condition in Central Region of Uttar Pradesh. International Journal of Modern Plant \& Animal Sciences, 2014, 2(1): 26-32.

Majeed, S., Sharma, D., 2006. Assessment of genetic divergence of Kala zeera of different geographical races from India. Proceedings of 1st Int. Conf. on Biotech. Approaches for alleviating malnutrition and human health. UAS, Bangalore, p. 191.

Pank, F., Quilitzsch, R., 1996. Phenotypical variability annual caraway (Carum carvi L. annuum hort.) in the central German crop area. Zeitschrift für Arznei und Gewurzpflanzen 1, 128-133.

Panse, V., 1957. Genetics of quantitative characters in relation to plant breeding. Indian J. Genet 17, 318-328.

Puschmann, G., Stephani, V., Fritz, D., 1992. Studies on the variability of Caraway (Carum carvi L). Gartenbauwissenschaft Books 57, 275-277 